\title{
Morfo-Physiological Response of Three Shallot Varieties on Water Surface Variation Level
}

\author{
Subandi Nur ${ }^{1}$, Suwarto $^{2}$, Saparso $^{2} \&$ Heru Adi Djatmiko ${ }^{2}$ \\ ${ }^{1}$ Departement of Agrotecnology, Faculty of Agriculture, University of Swadaya Gunung Jati, Cirebon, Indonesia \\ ${ }^{2}$ Departement of Agrotecnology, Faculty of Agriculture, University of Jenderal Soedirman, Purwokerto, Indonesia \\ Correspondence: Subandi Nur, Faculty of Agriculture, Swadaya Gunung Jati University. Jl. Pemuda Raya No.32, \\ Cirebon Sub-District, West Java Province, Indonesia. E-mail: subandi.nur1005@gmail.com
}

Received: February 22, 2020; Accepted: April 8, 2020; Published: April 9, 2020

\begin{abstract}
The morpho-physiological response study of three shallots varieties on the water surface variation level of the trench aims to find plants that are tolerant of water shortages. The study was conducted in the rice fields of Pulosari village, Brebes District, Brebes Regency, Central Java, Indonesia for three months (January to March 2019). The experimental design used was a separate plot design with three replications. The main plot of trench water surface height $(\mathrm{T})$ is $\mathrm{T} 1=10 \mathrm{~cm}, \mathrm{~T} 2=20 \mathrm{~cm}$ and $\mathrm{T} 3=30 \mathrm{~cm}$. The subplots of shallot variety $(\mathrm{V})$ are $\mathrm{V} 1=\mathrm{Bima}, \mathrm{V} 2=$ Yellow and V3 = Sumenep. The data obtained were analyzed using analysis of variance at 5\% error level, if there is a real difference found, the study would be followed by the Least Significant Difference Test (LSD) level 5\%. The results showed that the condition of water shortage was very influential on the morpho-physiological response of three shallots varieties.
\end{abstract}

Keywords: trench water, varieties, morpho-physiology, shallots

\section{Introduction}

Shallot is one of important commodity besides chili and potatoes. Shallot plants need regular irrigation. Soil moisture is an important factor that influences the shallot yield, because shallot takes very few water from at a depth of $0.6 \mathrm{~m}$, but takes more water at a depth of $0.3 \mathrm{~m}$ from the soil surface. Thus the topsoil area must be kept moist to stimulate root growth and provide sufficient water for plants (Huang et al., 2013); (Fauziah et al., 2016). As stated by Suwandi and Hilman (1995) environmental factor that determine the success of shallot plants is the availability of water. The amount and time of irrigation that must be given to plants depends on the climatic conditions, soil water content, plant growth rate and plant root characteristics. In shallot plants water shortages generally occur in the tuber formation period, so that it can reduce production, whereas tuber formation is a critical period for shallot plants. To overcome this problem, it is necessary to adjust the ground water level.

The availability of sufficient water for plants is very important. Water is not only a vital component for every life and also an important nutrition for plants. Water acts as a solvent for various organic molecular compounds (nutrients) in the soil to plants, a medium for transporting organic and inorganic solutes, maintaining cell turgidity, a raw material for photosynthesis, hydrolysis processes and other chemical reactions in plants and temperture regulators plant. Because of the high water demand and importance of water, plants need a constant source of water to grow and develop.

If the availability of ground water is lacking for plants, consequently water as a raw material for photosynthesis and nutrient transportation to the leaves will be hampered, so that it will have an impact on production produced by plants (Gardner et.al., 1991, Salisbury and Ross, 1995 and Saidi, 2006).

The land management system for shalllot cultivation is carried out in a surjan manner, that makes land beds with height (depth of trench) between $60-70 \mathrm{~cm}$. The water channel (trench) is filled with much water as to save some water in the soil (BPTP, 2000). Asdak (2010) said that water moves from places with high humidity potential to places with lower humidity potential. The movement of ground water through a certain soil volume occurs through the pore space of the soil caused by gravity and capillary forces. If soil moisture is optimum for plant growth, large amounts of water in intermediate-sized pore spaces in the soil can move and can be used by plants. The ability of plants to get water is determined by several things, including the ability of plant roots to absorb and use water in contact and ground water velocity to move in to replace the water used by plants (Saidi, 2006). 
Shallot production can be increased with the use of local, national and superior varieties introduced. The seeds must meet several requirements, namely the right variety, quantity, quality, time, location and price. Yet the availability of shallot seeds in the country is still unsufficient from these requirements (Azmi et al., 2011).

The development and evaluation of available shallot varieties are sustainable strategy to increase the productivity and production of shallots. The development of new varieties is a long and expensive process that also needs special handling. However, evaluation of existing shallot varieties to adapt to production in certain environmental conditions is a faster way to increase shallot production. Farmers choose varieties for planting depending on a number of factors which include production potential, market demand, ability to adapt to the environment, availability of seeds and prices (Mitiku and Tadesse, 2018). Muhamad (2010) said that the use of tolerant varieties is one of the most efficient and inexpensive technology choices.

The pigment that plays a role in the process of photosynthesis of plants by absorbing and converting light into chemical energy is chlorophyll. Chlorophyll is the main factor influencing photosynthesis. Photosynthesis is the process of changing inorganic compounds $\left(\mathrm{CO}_{2}\right.$ and $\left.\mathrm{H}_{2} \mathrm{O}\right)$ into organic compounds (carbohydrates) and $\mathrm{O}_{2}$ with the help of sunlight. Lack of water affects all aspects of plant growth, which includes physiological, biochemical, anatomical and morphological processes. When there is a lack of water, some leaf stomata close, resulting in the entry of $\mathrm{CO} 2$ and reduce photosynthetic activity. Besides inhibiting photosynthetic activity, lack of water also inhibits protein synthesis and cell walls. Plants that experience water shortages in general have smaller sizes compared to plants that grow normally (Salisbury and Ross, 1995 and Rosawanti, 2016).

Proline is amino acid which its concentration will increase compared to other amino acids in conditions of moderate to severe water shortages. Proline accumulation occurs when the water content of the media reaches less than $20 \%$ (Kurniawati et al., 2014). Water for plants plays an important role as a solvent and a chemical reaction medium, a transport medium, a medium to provide turgor to cells, charge hydration and neutralization in colloid molecules, raw material for photosynthesis and transpiration to cool plants. Plants experiencing drought stress will try to make physiological changes as a form of adaptation. One form of adaptation is the ability of plants to maintain turgor pressure or osmotic adjustment.

A large body of data suggests a positive correlation between proline accumulation and plant stress. Proline, an amino acid, plays a highly beneficial role in plants exposed to various stress conditions. Proline can function as a source of energy, nitrogen and carbohydrates (Garder et al., 1991and Hayat et al., 2012). Proline is a biochemical or osmotic metabolic compound which is synthesized and accumulated in various plant tissues, especially in the leaves when the plant faces drought stress. Plants that accumulate proline in the condition of choking generally have better morphological appearance and have higher survival than plants who did not accumulate it. Proline accumulation occurs when roots are conditioned under low water potential (Raymond and Smirnoff, 2002 and Hamim et al., 2008 in Nugraheni 2010).

Each plant variety has a very complex reaction in the face of drought stress as indicated by changes in morphology and physiology of different plants (Rosawanti P., 2016). The present research aims to find out the morphophysiological response of three varieties of shallots on the variation in surface water level of the trench.

\section{Materials and Methods}

Materials needed are seeds of three varieties of shallots (Bima, Yellow and Sumenep), inorganic fertilizers (ZA, Urea, SP-36 and $\mathrm{KCl}$ ), water and pesticides. The tools needed are scales, stationery, rulers, hoes, buckets, hand sprayers, dirt, soil thermometers, prolin testers and thermohygrometers.

The experiment was carried out using a separate plot design with 3 (three) replications. The main plot is the variation in surface height of the trench $(\mathrm{T})$, consisting of $\mathrm{T} 1=10 \mathrm{~cm}, \mathrm{~T} 2=20 \mathrm{~cm}$ and $\mathrm{T} 3=30 \mathrm{~cm}$. Subplots are shallot varieties (V), consisting of V1 = Bima, V2 = Yellow and V3 = Sumenep (Gomes KA and AA. Gomes, 1995). Based on the design, there were 9 treatment combinations, with 3 replications, there were 27 experimental plots from ( 3 X $3 \times 3)$. Each experimental plot consisted of 50 plants with spacing of $20 \mathrm{~cm} \mathrm{X} 20 \mathrm{~cm}$. Plant maintenance (fertilizing, weeding, pest control) is carried out intensively. Observations were made on the research variables, namely: a. Plant height, b. Number of leaves, c. Number of tillers, d. Root length, e. Stomatal opening width, f. Proline levels, g. Fresh tuber weight and h. Dry tuber weight.

The data obtained was analyzed using analysis of variance at $5 \%$ error level, if there is a real difference followed by the Least Significant Difference Test (LSD) 5\%.

\section{Results and Discussion}

The results of the statistical analysis in Table 1 . show that the varieties did not have a significantly different response to proline levels, whereas the plant height, number of leaves, number of tillers, root length and stomata 
opening width of varieties had significantly different responses. Trench water level significantly affected plant height, number of leaves, root length, stomata opening width and proline content, while the number of tillers had no significant effect. The interaction of varieties with the height of the trench water surface significantly affected plant height, number of leaves, root length and width of the stomata opening, whereas the levels of proline had no significant effect.

Table 1. Characteristic results of three varieties of shallots for high treatment surface of trench water.

\begin{tabular}{llll}
\hline Variable & Variety & Height trance water surface (T) & Interaction \\
\hline Plant heigh $(\mathrm{cm})$ & $* *$ & $* *$ & $* *$ \\
Number of Leaves & $* *$ & $* *$ & $* *$ \\
Number of tillers & $* *$ & $\mathrm{~ns}$ & $\mathrm{~ns}$ \\
Root lenght $(\mathrm{cm})$ & $* *$ & $* *$ & $* *$ \\
Stomata width opening & $* *$ & $* *$ & $\mathrm{~ns}$ \\
Prolin content $(\mu \mathrm{mol} / \mathrm{g})$ & $\mathrm{ns}$ & $* *$ & $* *$ \\
Fresh tuber weight & $* *$ & $\mathrm{~ns}$ & $* *$ \\
Dry tuber weight & $* *$ & $\mathrm{~ns}$ &
\end{tabular}

Note :

** :has very real influence

* :has real influence

ns :has no real influence

$\mathrm{T}$ :water trench height

V :Variety

VT :Interaction of variety with water trench height.

\subsection{Plant Growth}

Table 2. Shows that the shallot plant height is affected by varieties at the age of 4 WAP and 8 WAP, whereas at 6 WAP the variety has no significant effect. Sumenep variety has the highest plant height at the age of 8 MST (34.08 $\mathrm{cm})$, then followed by the Bima variety $(29.56 \mathrm{~cm})$ and Yellow variety $(29.36 \mathrm{~cm})$.

Table 2. Effect of trench varieties and water level on the height of shallot plants

\begin{tabular}{llcc}
\hline \multirow{2}{*}{ Treatment } & \multicolumn{3}{c}{ Age of plant (Weeks After Planting/WAP) } \\
\cline { 2 - 4 } & 4 & 6 & 8 \\
\hline Variety(V) & & & \\
Bima (V1) & $31,09 \mathrm{~b}$ & $32,05 \mathrm{a}$ & $29,56 \mathrm{a}$ \\
Yellow (V2) & $31,89 \mathrm{~b}$ & $31,38 \mathrm{a}$ & $29,36 \mathrm{a}$ \\
Sumenep (V3) & $28,26 \mathrm{a}$ & $31,57 \mathrm{a}$ & $34,08 \mathrm{~b}$ \\
Water surface trence level(T) & & & \\
$10 \mathrm{~cm}$ (T1) & $29,81 \mathrm{a}$ & $32,45 \mathrm{a}$ & $32,79 \mathrm{~b}$ \\
$20 \mathrm{~cm}$ (T2) & $30,22 \mathrm{ab}$ & $31,41 \mathrm{a}$ & $30,54 \mathrm{a}$ \\
$30 \mathrm{~cm}$ (T3) & $31,23 \mathrm{~b}$ & $31,14 \mathrm{a}$ & $29,70 \mathrm{a}$ \\
\hline
\end{tabular}

The numbers followed by the same letters in one line show no significant difference after 5\% LSD was tested.

Trench water level also affects the height of shallot plants. The treatment of trench water level influences the height at the age of $4 \mathrm{WAP}$ and $8 \mathrm{WAP}$, while at $6 \mathrm{WAP}$ there is no significant effect. The treatment of trench water level of $10 \mathrm{~cm}$ had the highest plant height at the age of $8 \mathrm{MST}(32.79 \mathrm{~cm})$, then followed the height of trench water level of $20 \mathrm{~cm}(30.54 \mathrm{~cm})$ and trench water level of $30 \mathrm{~cm}(29.70 \mathrm{~cm})$.

In Table 3 it can be seen that different varieties affect the number of leaves of shallot plants at the age of 4 WAP, $6 \mathrm{WAP}$ and 8 WAP. Sumenep varieties produce more leaves than Bima and Yellow varieties. This is likely the plant height and number of leaves are largely determined by genetic factors, Sumenep varieties are also relatively more able to adapt to existing environmental conditions compared to Bima and Yellow varieties. As stated by Azmi C., et al. (2011) and Baswarsiati (2009), plant phenotypics are determined by interactions between genetics 
(varieties) and the environment. Sumenep variety has a broad adaptability in several agroecology in the lowlands to the highlands.

Table 3. Effect of variety and water surface level on the number of leaves of shallot plants.

\begin{tabular}{llcc}
\hline Treatment & \multicolumn{3}{c}{ Age of plant (Weeks After Planting/WAP) } \\
\cline { 2 - 4 } & 4 & 6 & 8 \\
\hline Variety(V) & & & \\
$\quad$ Bima (V1) & $19,34 \mathrm{ab}$ & $21,17 \mathrm{~b}$ & $16,80 \mathrm{a}$ \\
Yellow (V2) & $18,35 \mathrm{a}$ & $19,23 \mathrm{a}$ & $16,00 \mathrm{a}$ \\
Sumenep (V3) & $19,70 \mathrm{~b}$ & $24,70 \mathrm{c}$ & $26,65 \mathrm{~b}$ \\
Trench water level surface(T) & & & \\
$10 \mathrm{~cm}(\mathrm{~T} 1)$ & $18,44 \mathrm{a}$ & $22,49 \mathrm{~b}$ & $22,21 \mathrm{~b}$ \\
$20 \mathrm{~cm}$ (T2) & $18,88 \mathrm{a}$ & $21,40 \mathrm{a}$ & $18,93 \mathrm{a}$ \\
$30 \mathrm{~cm}$ (T3) & $20,08 \mathrm{~b}$ & $21,22 \mathrm{a}$ & $18,31 \mathrm{a}$ \\
\hline
\end{tabular}

The numbers followed by the same letters in one line show no significant difference after 5\% LSD was tested.

Trench water level influences the number of leaves of shallot plants at the age of 4 WAP, 6 WAP and 8 WAP (Table 3). Trench water level of $10 \mathrm{~cm}$ gives a greater number of leaves than trench water level of $20 \mathrm{~cm}$ and 30 $\mathrm{cm}$. It is assumed that the height of trench water level of $10 \mathrm{~cm}$ is the most suitable condition, so that at a height of trench water level of $10 \mathrm{~cm}$ the plant can grow well, finally giving the highest response. It was said by Sumarni and Hidayat (2005), that although shallot plants do not need a lot of rain, but planting shallots require sufficient water during their growth.

The effect of interaction varieties with trench water level on the height of shallot plants is shown in Table 4 . The height of shallots plants of Bima variety and Yellow varieties increased at trench water level of $10 \mathrm{~cm}, 20 \mathrm{~cm}$ and $30 \mathrm{~cm}$, while Sumenep variety did not show differences in trench water level at the height of $10 \mathrm{~cm}, 20 \mathrm{~cm}$ and 30 $\mathrm{cm}$.

Table 4. Effect of interaction between varieties and trench water level on the height of shallot plants

\begin{tabular}{llll}
\hline & \multicolumn{4}{l}{ Height of trench water level $(\mathrm{T})$} & $30 \mathrm{~cm}$ \\
\cline { 2 - 3 } Bima & $10 \mathrm{~cm}$ & $20 \mathrm{~cm}$ & $33,02 \mathrm{~b} \mathrm{~B}$ \\
Yellow & $27,64 \mathrm{aA}$ & $28,02 \mathrm{aA}$ & $29,05 \mathrm{~b} \mathrm{~A}$ \\
Sumenep & $27,95 \mathrm{aA}$ & $29,05 \mathrm{~b} \mathrm{~A}$ & $34,24 \mathrm{a} \mathrm{B}$ \\
\hline
\end{tabular}

The numbers followed by the same lowercase in one line show no significant difference after 5\% LSD was tested. The numbers followed by the same capital letter in one column show no significant difference after 5\% LSD was tested.

This difference in adaptation is likely due to each variety that has been tested has different response to the existing environmental conditions. As stated by Irianto, et al., (2017) each shallot variety has distinct ability to adapt as it needs planting test in the other region.

The leaves number of Bima, Yellow and Sumenep varieties increased with the height of the trench water level (Table 5). It is assumed that three varieties of shallot plants which were tested respond well to the trench surface water level. As stated by Mubarak, I. and Hamdan, A., (2005), the shallot plant requires sufficient water during its growth, because onion crop was found to be sensitive to water deficit during the whole growing season.

Table 5. Effect of interaction between varieties and trench water level on shallot leaves.

\begin{tabular}{llll}
\hline & \multicolumn{2}{l}{ Trench water level (T) } & \\
\cline { 2 - 4 } Bima & $10 \mathrm{~cm}$ & $20 \mathrm{~cm}$ & $30 \mathrm{~cm}$ \\
Yellow & $20,11 \mathrm{~b} \mathrm{~B}$ & $15,17 \mathrm{aA}$ & $15,11 \mathrm{aA}$ \\
Sumenep & $16,60 \mathrm{~b} \mathrm{~A}$ & $16,04 \mathrm{ab} \mathrm{A}$ & $15,37 \mathrm{aA}$ \\
\hline
\end{tabular}


The numbers followed by the same lowercase in one line show no significant difference after 5\% LSD was tested. The numbers followed by the same capital letter in one column show no significant difference after 5\% LSD was tested.

\subsection{Crop Yields}

Variety differences affect the number of shallot plants only at the age of 8 MST (Table 6). Sumenep varieties produce more number of tillers ( 7.83 tillers) compared to Bima varieties ( 7.44 tillers) and Yellow varieties ( 7.42 tillers). It is suspected that the number of shallots saplings is strongly influenced by genetic factors. Bima variety has the potential number of tillers ( $7-12$ tillers), Yellow varieties (7-13 tillers) and Sumenep varieties (7-14 tillers) (BPTP, 2000).

Table 6. Effect of variety and height of trench water level on the number of shallot plants.

\begin{tabular}{llcc}
\hline \multirow{2}{*}{ Treatment } & \multicolumn{4}{c}{ Age of plant (Weeks After Planting/WAP) } \\
\cline { 2 - 4 } & 4 & 6 & 8 \\
\hline Variety(V) & & & \\
Bima (V1) & $4,24 \mathrm{a}$ & $6,51 \mathrm{a}$ & $7,44 \mathrm{a}$ \\
Yellow (V2) & $4,14 \mathrm{a}$ & $6,48 \mathrm{a}$ & $7,42 \mathrm{a}$ \\
Sumenep (V3) & $4,23 \mathrm{a}$ & $6,60 \mathrm{a}$ & $7,83 \mathrm{~b}$ \\
Trench water level (T) & & & \\
$10 \mathrm{~cm}$ (T1) & $4,45 \mathrm{~b}$ & $6,66 \mathrm{a}$ & $7,53 \mathrm{a}$ \\
$20 \mathrm{~cm}$ (T2) & $4,15 \mathrm{a}$ & $6,48 \mathrm{a}$ & $7,55 \mathrm{a}$ \\
$30 \mathrm{~cm}$ (T3) & $4,01 \mathrm{a}$ & $6,47 \mathrm{a}$ & $7,61 \mathrm{a}$ \\
\hline
\end{tabular}

The numbers followed by the same letters in one line show no significant difference after 5\% LSD was tested.

Trench water level has an effect on the number of shallot plants at 4 WAP, while at $6 \mathrm{WAP}$ and 8 WAP there is no significant effect (Table 6). Trench water level of $10 \mathrm{~cm}$ gives a higher number of tillers than trench water level of $20 \mathrm{~cm}$ and $30 \mathrm{~cm}$. It is assumed that the height of trench water level of $10 \mathrm{~cm}$ is relatively the most appropriate condition at the beginning of the formation of tillers, so that at the surface height of trench water $10 \mathrm{~cm}$ the plant can grow well, finally giving the highest response. As stated by Suwandi and Hilman (1995) environmental factors determine the success of shallot plants is water availability. In shallot plants water shortages generally occur in the tuber formation period, so that it can reduce production, whereas tuber formation is a critical period for shallot plants.

Table 7 shows the differences between fresh tuber weights and dry tuber weights. The highest difference for these variables is owned by Sumenep (V3) and followed by Bima (V1) and Yellow (V2). This is probably because the Sumenep (V3) variety is relatively more adaptable to the existing environmental conditions than other varieties, so it can develop more optimally. Plant phenotypes are determined by interactions between genetic and environmental factors, and varieties that are tolerant of the environment have self defense mechanisms so that their growth and production are not affected (Azmi et al., 2011).

Tabel 7. Effect of varieties and trench water level on fresh tuber weights and dried tuber weights on shallots.

\begin{tabular}{lll}
\hline Treatment & Fresh tuber weight (g/plot) & Dry tuber weight $(\mathrm{g} /$ plot $)$ \\
\hline Variety(V) & & \\
Bima (V1) & $226,35 \mathrm{a}$ & $177,55 \mathrm{a}$ \\
Yellow (V2) & $218,59 \mathrm{a}$ & $173,51 \mathrm{a}$ \\
Sumenep (V3) & $295,29 \mathrm{~b}$ & $223,12 \mathrm{~b}$ \\
PAP Height & & \\
$10 \mathrm{~cm}(\mathrm{~T} 1)$ & $253,61 \mathrm{a}$ & $196,27 \mathrm{a}$ \\
$20 \mathrm{~cm}(\mathrm{~T} 2)$ & $251,70 \mathrm{a}$ & $193,90 \mathrm{a}$ \\
$30 \mathrm{~cm}(\mathrm{~T} 3)$ & $234,92 \mathrm{a}$ & $184,01 \mathrm{a}$ \\
\hline
\end{tabular}

The numbers followed by the same letters in one line show no significant difference after 5\% LSD was tested. The treatment of trench water level height for fresh tuber weights, trench water level of $10 \mathrm{~cm}$ (T1) has fresh tuber weight $(253.61 \mathrm{~g} /$ plot) and higher but not significantly different from fresh tuber weight with trench water level 
height $20 \mathrm{~cm}$ (T2), ie weighing (251.70 g / plot) and trench water level $30 \mathrm{~cm}$ (T3) $(234.92 \mathrm{~g} /$ plot). This is probably due to the shallot plants with trench water surface height of $10 \mathrm{~cm}$ is relatively slightly easier to get water compared to the height of trench water level of $20 \mathrm{~cm}$ and $30 \mathrm{~cm}$, then the growth is relatively slightly better because getting a relatively more suitable environment. This is consistent with what was said by Enchalew B. et al. (2016), that onion plants are relatively sensitive to water stress, this can cause yields and quality to be below expectations. Also said by Kandil et al. (2011) that, soils that suffer from water shortages during the growth stages lead to a reduction in shallot yield. It added that shallots are more sensitive to stress deficiency in water during the formation and enlargement of tubers than during the vegetative growth stage.

\subsection{Morfo-Physicological Character}

One mechanism of plant resistance to drought stress is to avoid the stress condition. Morpho-physiological mechanism of plants to avoid drought stress is the ability of plants to extend their roots to find water sources far from the surface of the soil during drought stress in areas near the surface of the soil. Another mechanism of resistance to drought is to reduce the width of the stomata opening and the ability of plants to produce proline compounds (Gardner et al., 1991 and Muhamad, 2010).

Table 8 shows that varieties affect the diversity of root length of shallot plants. In 8 WAP plants, the Sumenep variety had the highest plant root length $(32.89 \mathrm{~cm})$, followed by the Bima variety $(28.40 \mathrm{~cm})$ and Yellow variety $(27.79 \mathrm{~cm})$. This is likely due to the Sumenep variety being relatively more adaptable to the environment compared to Bima and Yellow varieties. Thus the roots of the Sumenep variety have relatively better growth compared to the roots of the Bima and Yellow varieties. As stated by Gardner et al. (1991) root characteristics are quantitatively controlled by a number of genes, these genetic differences then interact with the soil environment.

Table 8 . Effect of variety and trench water level on the root length of shallot plants.

\begin{tabular}{llcc}
\hline \multirow{2}{*}{ Treatment } & \multicolumn{3}{c}{ Age of plant (Weeks After Planting/WAP) } \\
\cline { 2 - 4 } & 4 & 6 & 8 \\
\hline Variety(V) & $22,02 \mathrm{a}$ & $25,29 \mathrm{a}$ & $28,40 \mathrm{a}$ \\
Bima (V1) & $21,89 \mathrm{a}$ & $24,98 \mathrm{a}$ & $27,79 \mathrm{a}$ \\
Yellow (V2) & $27,02 \mathrm{~b}$ & $30,33 \mathrm{~b}$ & $31,65 \mathrm{~b}$ \\
Sumenep (V3) & & & \\
Trench water level (T) & $23,94 \mathrm{a}$ & $27,03 \mathrm{a}$ & $28,64 \mathrm{a}$ \\
$10 \mathrm{~cm}$ (T1) & $23,01 \mathrm{a}$ & $26,48 \mathrm{a}$ & $29,02 \mathrm{ab}$ \\
$20 \mathrm{~cm}$ (T2) & $24,00 \mathrm{a}$ & $27,11 \mathrm{a}$ & $30,18 \mathrm{~b}$ \\
$30 \mathrm{~cm}$ (T3) & & & \\
\hline
\end{tabular}

The numbers followed by the same letters in one line show no significant difference after 5\% LSD was tested.

Trench water level influences the root length of shallot plants at the age of 8 WAP, whereas at 4 WAP and 6 WAP there is no significant effect (Table 8 and Figure 1). Trench water level $30 \mathrm{~cm}$ gives a higher root length compared to the trench water level of $20 \mathrm{~cm}$ and $10 \mathrm{~cm}$. It is assumed that the height of the trench water level of $30 \mathrm{~cm}$ is relatively the most difficult condition for the shallot plants to get water, so that the plants make adjustments with the intention of finding a water source by extending the roots. 


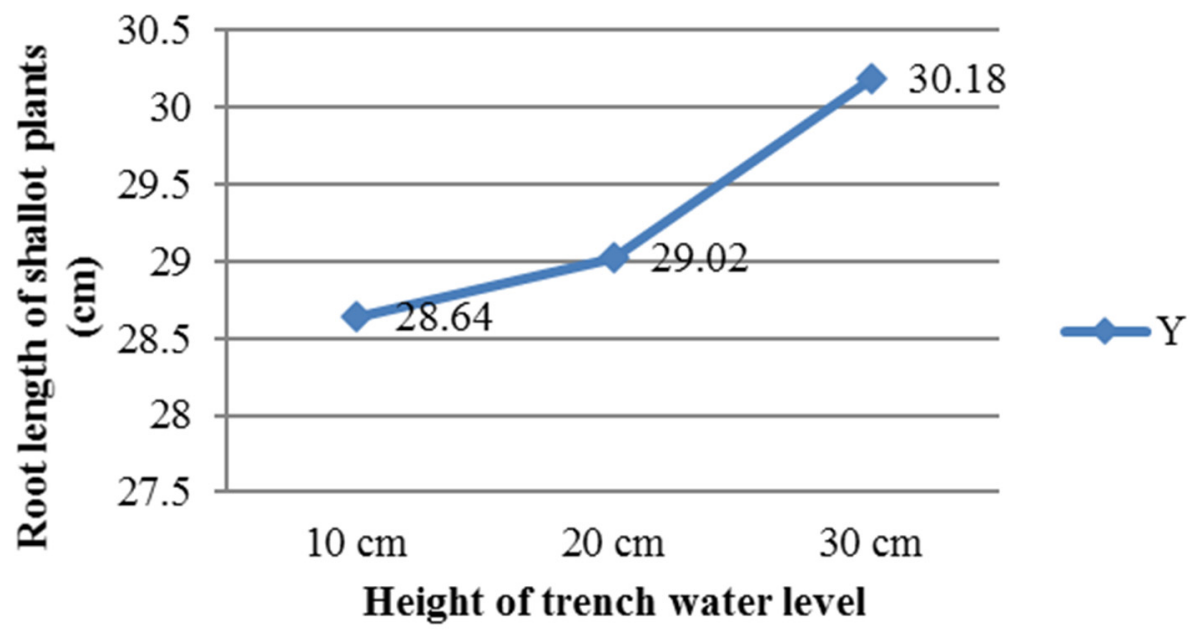

Figure 1. Effect of height trench water level on root length of shallot plants.

Shallot plants require crumb structured soil, medium to clay texture, good aeration and contain sufficient organic matter (Sumarni and Hidayat, 2005). Shallot plants take very little water from a depth of $0.6 \mathrm{~m}$, but take more water at a depth of $0.3 \mathrm{~m}$ from the soil surface. Thus the topsoil area must be kept moist to stimulate root growth and provide sufficient water for plants (Mutetwa \& Mtaita, 2014); (Nandle et al., 2018).

Table 9. Effect of interaction of varieties and trench water level on the root length of shallot.

\begin{tabular}{llll}
\hline Varieties & \multicolumn{3}{l}{ Trench water level (T) } \\
\cline { 2 - 4 } & $10 \mathrm{~cm}$ & $20 \mathrm{~cm}$ & $30 \mathrm{~cm}$ \\
Bima & $30,26 \mathrm{~b} \mathrm{~B}$ & $27,61 \mathrm{aA}$ & $27,34 \mathrm{aA}$ \\
Yellow & $26,03 \mathrm{aA}$ & $27,21 \mathrm{ab} \mathrm{A}$ & $28,13 \mathrm{~b} \mathrm{~A}$ \\
Sumenep & $31,29 \mathrm{a} \mathrm{B}$ & $33,12 \mathrm{~b} \mathrm{~B}$ & $34,25 \mathrm{~b} \mathrm{~B}$ \\
\hline
\end{tabular}

The numbers followed by the same lowercase in one line show no significant difference after 5\% LSD was tested. The numbers followed by the same capital letter in one column show no significant difference after 5\% LSD was tested.

The root length of the shallot Bima variety increases with the height of the trench water level. Whereas the root length of the Yellow variety and Sumenep variety are increasing with decreasing trench water surface height (Table 9). It is suspected that the Bima variety responded positively to the height of the surface of the trench water level, so that the higher the surface of the trench water level the longer the root of the shallot plant. As for the Yellow and Sumenep varieties, it is assumed to be more suitable for the height of the trench water level of $30 \mathrm{~cm}$, so that with the lower height of the trench water level the root length increases. Shallot plants have shallow root systems and are very susceptible to loss of moisture from the topsoil, so efficient irrigation must be provided to maintain their growth Although shallot plants do not require a lot of rain, onion plants require sufficient water during their growth (Sumarni and Hidayat, 2005); (Patel, N. and Rajput, T.B.S., 2013).

Table 10. shows that the variety influences the wide width of the shallot leaf stomata opening width. Yellow variety has the highest stomata openings $(7.56 \mu \mathrm{m})$, followed by Bima varieties $(7.05 \mu \mathrm{m})$ and Sumenep varieties $(6.81$ $\mu \mathrm{m})$. The Sumenep variety has relatively lower stomata openings compared to the Yellow and Bima varieties, it is suspected that the Sumenep variety is relatively more resistant to drought stress. Haryanti and Meirina (2009) said that the wider the stomata opening, the transpiration rate will be higher, so it is assumed that plants which have high stomata opening width are less adaptive to drought stress. In general,shallot was planted in low land to highland, but it usually planted in area has rain fall and humidity not high, because can effect to the yielding, so that needed the adaptive varieties in the condition Marpaung and Rosliani (2019). 
Table 10. Effect of varieties and trench water level on shallot plant physiology variables

\begin{tabular}{lll}
\hline Treatment & Stomata width opening & Prolin conten \\
\hline Variety(V) & & \\
Bima (V1) & $7,05 \mathrm{a}$ & $4,96 \mathrm{a}$ \\
Yellow (V2) & $7,56 \mathrm{~b}$ & $4,20 \mathrm{a}$ \\
Sumenep (V3) & $6,81 \mathrm{a}$ & $4,20 \mathrm{a}$ \\
PAP Height & & \\
$10 \mathrm{~cm}(\mathrm{~T} 1)$ & $7,66 \mathrm{~b}$ & $3,68 \mathrm{a}$ \\
$20 \mathrm{~cm}(\mathrm{~T} 2)$ & $7,17 \mathrm{~b}$ & $4,15 \mathrm{ab}$ \\
$30 \mathrm{~cm}(\mathrm{~T} 3)$ & $6,58 \mathrm{a}$ & $5,53 \mathrm{~b}$ \\
\hline
\end{tabular}

The numbers followed by the same letters in one column in the same treatment, are not significantly different after being tested for LSD 5\%.

Trench water level influences the width of the stomata opening (Table 10 and Figure 2). The highest width of the stomata opening is indicated by the treatment of trench water level $10 \mathrm{~cm}(7.66 \mu \mathrm{m})$, followed by the treatment of trench water level $20 \mathrm{~cm}(7.17 \mu \mathrm{m})$ and trench water level treatment of $30 \mathrm{~cm}(6.58 \mu \mathrm{m})$.

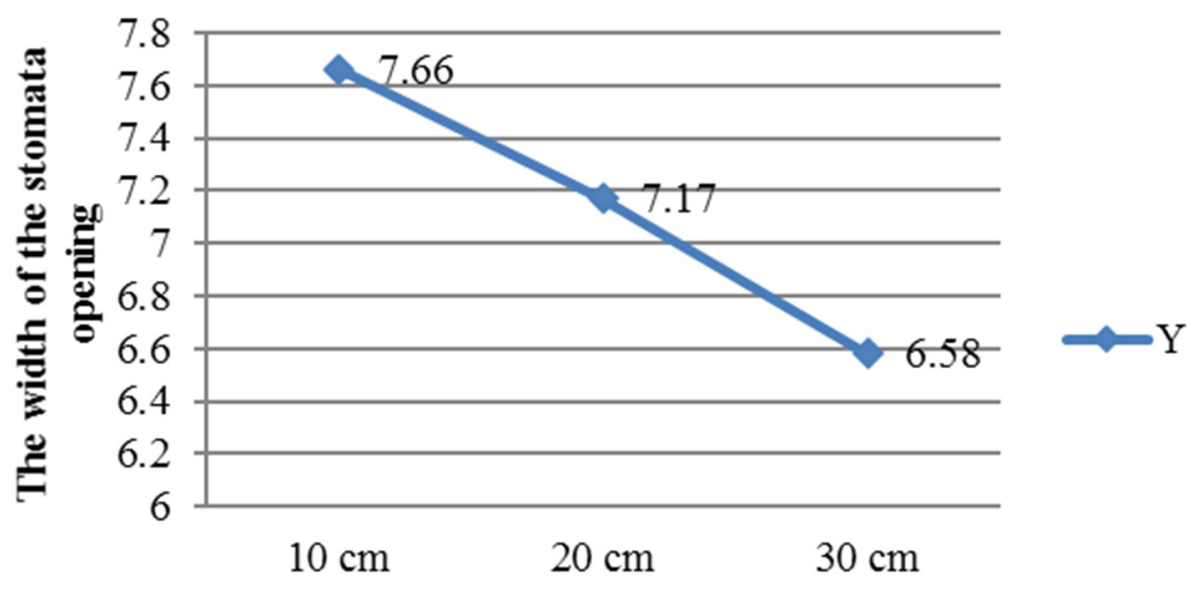

Height of trench water level

Figure 2. Effect of height trench water level on the width of the stomata opening.

The increasing width of stomata opening with the height of trench surface water level is allegedly due to the increasing height of trench water level, the distance between the water source and the place where the plants grow closer. Water moves from places with high humidity potential to places with lower humidity potential (Asdak, 2010). As stated by Lakitan (2012) the opening of the stomata is due to the increased turgor pressure of the escort cells compared to the surrounding cells, therefore lack of water can reduce the opening of the stomata.

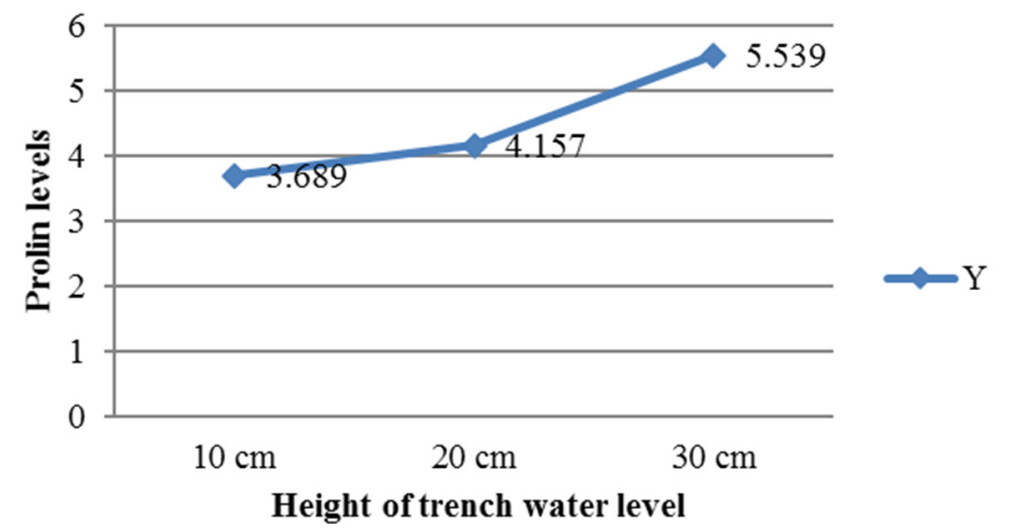

Figure 3. Effect of height trench water level on proline levels 
Trench water level also affects proline levels (Table 10 and Figure 3). The highest level of proline was indicated by the treatment of trench water level $30 \mathrm{~cm}(5.53 \mu \mathrm{mol} / \mathrm{g})$, followed by the treatment of trench water level 20 $\mathrm{cm}(4.15 \mu \mathrm{mol} / \mathrm{g})$ and trench water level treatment of $10 \mathrm{~cm}(368 \mu \mathrm{mol} / \mathrm{g})$. It is assumed that the height of trench water level of $30 \mathrm{~cm}$ is the lowest relative humidity condition, so that at the surface water level of the trench $30 \mathrm{~cm}$ more proline is produced. Hayat et al. (2012) said that a stressful environment results in an overproduction of proline in plants which in turn imparts stress tolerance by maintaining cell turgor or osmotic balance, andhigh levels of proline when drought stress is a clue in the mechanism of shallot adaptation to drought stress.

Table 11. Effect of interaction between varieties and height of trench water level on the width of the onion stomata opening.

\begin{tabular}{lccc}
\hline \multirow{2}{*}{ Varieties } & \multicolumn{3}{c}{ Trench water level (T) } \\
\cline { 2 - 4 } Bima & $10 \mathrm{~cm}$ & $20 \mathrm{~cm}$ & $30 \mathrm{~cm}$ \\
Yellow & $7,54 \mathrm{~b} \mathrm{~B}$ & $6,88 \mathrm{aA}$ & $6,71 \mathrm{aA}$ \\
Sumenep & $8,37 \mathrm{c} \mathrm{C}$ & $7,92 \mathrm{~b} \mathrm{~B}$ & $6,38 \mathrm{aA}$ \\
\hline
\end{tabular}

The numbers followed by the same lowercase in one line show no significant difference after 5\% LSD was tested. The numbers followed by the same capital letter in one column show no significant difference after 5\% LSD was tested.

The effect of interaction of varieties and the height water level of trench water on the width of stomata openings of shallot plants is shown in Table 11. The width of stomata opening of shallot leaves of varieties of Bima, Yellow, and Sumenep varieties showed an increase and were different from the lower height of trench water surface $10 \mathrm{~cm}$, $20 \mathrm{~cm}$ and $30 \mathrm{~cm}$. This is suspected by the lower surface of the trench water, the humidity in the rooting area is relatively low, this condition is responded by plants by reducing the width of the stomata opening. Swasono (2012) said that stomata closure is a rapid response of plants, while stomata density occurs after the plants experience continuous drought stress in a certain time.

\section{Conclusions}

1. An interaction occurs between the variety and height of the trench water surface on plant height, number of leaves, root length, stomatal opening width, fresh tuber weight and dry tuber weight,

2. Sumenep variety produces higher growth (plant height, number of leaves) and yield (number of tillers, fresh tuber weight, dry tuber weight) compared to Bima and Yellow varieties,

3. Sumenep variety has morpho-physiological responses (root length, stomata opening width and proline levels) higher than Bima and Yellow varieties,

4. Trench water level of $10 \mathrm{~cm}$ (T1) is not much different from the height of trench water level of $20 \mathrm{~cm}$ (T2) and trench water level of $30 \mathrm{~cm}$ (T3) on growth variables and shallot yield variables.

5. Trench water level of $30 \mathrm{~cm}$ (T3) is significantly different from trench water level of $20 \mathrm{~cm}$ (T2) and trench water level of $10 \mathrm{~cm}$ (T1) in the morpho-physiological response of shallot plants.

6. Sumenep variety can be considered as an adaptive variety to be planted in the Brebes area and its surroundings.

7. Trench water level of $10 \mathrm{~cm}$ (T3) and trench water level of $20 \mathrm{~cm}$ (T2) can be considered, because the results are not significantly different from the treatment of trench water level of $10 \mathrm{~cm}(\mathrm{~T} 1)$.

8 Further research needs to be done on the response of shallot plant varieties to the treatment of trench water surface to obtain better growth and yield.

\section{Acknowledgement}

Thank you to the leadership and staff of the Faculty of Agriculture, Unsoed, Purwokerto, Central Java and Swadaya Gunung Jati University (UGJ), Cirebon, West Java.

\section{References}

Asdak, C. (2010). Hidrologi dan Pengelolaan Daerah Aliran Sungai. Gajah Mada University Press. Yogyakarta.

Azmi, C., Hidayat, I. M., \& Wiguna, G. (2011). Pengaruh Varietas dan Ukuran Umbi terhadap Produktivitas Bawang Merah. Jurnal Hortikultura. 21(3), 206-213. https://doi.org/10.21082/jhort.v21n3.2011.p206-213 
Balai Pengkajian Teknologi Pertanian. (2000). Teknologi Budidaya Bawang Merah. Petunjuk Teknis. Badan Penelitian dan Pengembangan Pertanian. Departemen Pertanian. Ungaran.

Baswarsiati. (2009). Budidaya Bawang Merah dan Penanganan Permasalahannya. Balai Pengkajian Teknologi Pertanian. Jawa Timur. Malang.

Enchalew, B., Gebre, S. L., Rabo, M., Hindaye, B., Kedir, M., \& Musa, Y. dan Shafi A. (2016). Effect of Deficit Irrigation on Water Productivity of Onion (Allium cepa L.) Under Drip Irrigation. Irrigation \& Drainage Systems Engineering, 5, 172. https://doi.org/10.4172/2168-9768.1000172

Fauziah, R., \& Sulistyono, E. dan Susila A. (2016). Budidaya Bawang Merah (Allium ascalonicum L.) pada Lahan Kering Menggunakan Irigasi Sprinkler pada berbagai Volume dan Frekuensi. Journal Hortikultura Indonesia. https://doi.org/10.2944/jhi.7.1.1-8

Gardner, F. P., Pearce, R. B., \& dan Mitchel, R. L. (1991). Physiology of Crop Plant. Universitas Indonesia-Press. Jakarta.

Gomes, K. A. \& dan Gomes, A. A. (1995). Prosedur Statistik Untuk Penelitian Pertanian. Edisi Kedua. Penerbit Universitas Indonesia (UI-PRESS). Jakarta. 698 hal.

Haryanti, \& dan Meirina T. (2009). Optimalisasi Pembukaan Porus Stomata Daun Kedelai (Glycine max (L) merril) Pada Pagi Hari dan Sore. Bioma, 11(1), 18-23. https://doi.org/10.14710/bioma.11.1.11-16.

Hayat, S., Hayat, Q., Alyemeni, M. N., Wani, A. S., Pichtel, J., \& Ahmad, A. (2012). Role of Proline Under Changing Environments. Plant Signaling \& Bihavior, 7(11), 1-11. https://doi.org/10.4161/psb.21949

Huang, G., Huang, Q., Wang, J., \& Pereira, L. S. (2012). Effects of water deficitson growth, yield and water productivity of drip irrigated onion (Allium cepa L.) in an arid region of Northwest China. Irrigation Science, 31, 995-1008. https://doi.org/10.1007/s00271-012-0378-5

Irianto, H., Yakup, U., \& Susilawati, S. (2017). Growth and Yield Characteristics of Tree Shallot Varieties Affacted by Phosphate Fertilizer Dosages on Ultisol. Russian Journal of Agricultural and Socio-Economic Sciences, 5(65). https://doi.org/10.18551/rjoas.2017-05.32

Kandil, A. A., Sharief, A. E., Attia, A. N. E., \& dan Leilh, A. A. A. (2011). Respons of Onion (Allium cepa L.) Yield to Water Stress and Mineral Biofertilization. Acta Agronomica Hungaria, 54(4), 361-370. https://doi.org/10.1556/AAgr.59.2011.4.7

Kurniawati, S., Khumaida, N., Ardie, S. W., Hartati, N. S., \& dan Sudarmonowati, E. (2014). Pola Akumulasi Prolin dan Poliamin Beberapa Aksesi Tanaman Terung Pada Cekaman Kekeringan. Journal Agronomi Indonesia, 42(2), 136-141. https://doi.org/10.24831/jai.v4212.8432

Lakitan, B. (2012). Dasar Dasar Fisiologi Tumbuhan. PT. Raja Grafindo Persada. Jakarta.

Marpaung, A. E., \& dan Rosliani, R. (2019). Adaptability of Growth and Yield on 5 Varieties of Shallot (Allium ascalonicum L.) in Wet Highland. Journal of Tropical Horticulture, 2(1). https://doi.org/10.33089/jthort.v2i1.12

Mubarak, I., \& Hamdan, A. (2018). Onion Crop Respons to Regulated Deficit Irrigation Under Mulching in Dry Mediterranean Region. Journal of Horticultural Research, 26(1), 87-94. https://doi.org/10.2478/johr-20180010

Muhamad, D. (2010). Pengaruh Cekaman Kekeringan Terhadap Pertumbuhan dan Beberapa Karakter MorfoFisiologi Tanaman Nilam. Buletin Penelitian Tanaman Rempah dan Obat(BUL LITTRO). 21(1), 8-17. Balai Penelitian Tanaman Obat dan Aromatik. Bogor.

Mutetwa, M., \& dan Mtaita, T. (2014). Effect of Mulching and Fertilizer Sources on Growth and Yield of Onion. Journal Global Innovation in Agricultural Social Sciences (JGIASS), 2(3), 102-106. https://doi.org/10.17957/JGIASS/2.3.561

Nandle, N., Sharma, R. K., Kushwah, S. S., \& Gallani, R. (2018). Effect of Irrigation Regims and Varietas on Growth, Bulb Yieldand Quality of Onion (Allium cepa L.). International Journal of Curren Microbiology and Applied Science, 7(5). https://doi.org/10.20546/ijcmas.2018.705.135

Nugraheni, W. (2010). Variasi Pertumbuhan, Kandungan Prolin dan Aktivitas Nitrat Reduktase Tanaman Ganyong (Canna edulis Ker.) Pada Ketersediaan Air Yang Berbeda. Thesis. Universitas Negeri Surakarta. Surakarta.

Patel, N., \& Rajput, T.B.S. (2013). Effect of Deficit Irrigation on Crop Growth, Yield and Quality of Onion in Subsurface Drip Irrigation. International Journal of Plant Production, 7(3), 417-426. 
https://doi.org/10.22069/ijpp.2013.1112

Rosawanti, P. (2016). Pengaruh Cekaman Kekeringan Terhadap Kandungan Klorofil danProlin Daun Kedelai. Anterior Journal, 15(2). https://doi.org/10.33084/anterior.v15i2.52

Saidi, A. (2006). Fisika Tanah dan Lingkungan. Andalas University Press. Padang.

Salisbury, F. B., \& dan Ross, C. W. (1995). Fisiologi Tumbuhan. Institut Teknologi Bandung. Edisi Keempat. PenerbitInstitut Teknologi Bandung. Bandung.

Sumarni, N., \& dan Hidayat, A. (2005). Panduan Teknis. Budidaya Bawang Merah. Balai Penelitian Tanaman Sayuran. Pusat Penelitian dan Pengembangan Hortikultura. Badan Penelitian dan Pengembangan Pertanian. Lembang Bandung.

Suwandi, \& dan Hilman, Y. (1995). Budidaya Tanaman Bawang Merah. Teknologi Produksi Bawang Merah. Pusat Penelitian dan Pengembangan Hortikultura. Badan Penelitian dan Pengembangan Pertanian. Jakarta.

Swasono, F. D. H. (2012). Peran ABA dan Prolina dalam Mekanisme Adaptasi Tanaman Bawang Merah Terhadap Cekaman Kekeringan di Tanah Pasir Pantai. Journal Agrisains, 4(5), 71-78. ISSN: 2541-5069.

\section{Copyrights}

Copyright for this article is retained by the author(s), with first publication rights granted to the journal.

This is an open-access article distributed under the terms and conditions of the Creative Commons Attribution license (http://creativecommons.org/licenses/by/4.0/). 